\title{
INFLUENCE OF SCHOOL RESOURCES ON ACADEMIC PERFORMANCE OF VISUALLY IMPAIRED LEARNERS IN INTEGRATED PUBLIC PRIMARY SCHOOLS IN BARINGO COUNTY, KENYA
}

\author{
Dinah Jepkorir Konga ${ }^{1}$, \\ Stephen Tomno Cheboi ${ }^{2 i}$ \\ ${ }^{1}$ Department of Special Needs Education, \\ Mount Kenya University, \\ Kenya \\ ${ }^{2}$ Dr, Department of Education Management \\ and Curriculum Studies, \\ Mount Kenya University, \\ Kenya
}

\begin{abstract}
:
Despite the provision of school resources by Kenyan government through the Ministry of Education, there has been an outcry from stakeholders owing to dismal performance among Visually Impaired Learners at Kenya Certificate of Primary Education examination in Marigat and Kabartonjo Sub-Counties. The purpose of this study was to establish the extent to which school resources influence academic performance of visually impaired learners in integrated primary schools in Baringo County. The study adopted mixed methods methodology where data was collected by use of questionnaires, interview, and observation guides to obtain both quantitative and qualitatively data, respectively. The target population involved501 participants comprising 2 head teachers, 68 regular teachers, 49 VI learners, 380 sighted learners and 2 Educational Assessment Resource Centers (EARC) officers. From this population, a total sample of298 participants was drawn. Simple random sampling technique was used to draw 59 regular teachers, 191 sighted learners and 44 VI learners, while 2 EARC officers and 2 head teachers were purposively sampled. Data was collected using questionnaires for teachers and sighted learners, interview guide for heard teachers and EARC, and observation checklist for Visually Impaired respondents. The tools were piloted to establish their reliability and adequately validated. The quantitative data was analyzed using descriptive statistics while thematic analysis was used for qualitative data. The study found out that inadequate learning materials was a major cause of low academic performance of VI learners in Marigat and Kabartonjo integrated public primary schools. It further established that there were inadequate learning resources, support services and a
\end{abstract}

i Correspondence: email stephencheboi@ymail.com 
learning environment that was not conducive for VI learners. The study recommends that the government provides more learning resources to VI learners and school management to provide barrier free learning environment. This study results would be of great value to teachers, parents, head teachers, schools, stakeholders, and Ministry of Education in enhancing academic performance of the V.I learners in Integrated schools.

Keywords: school resources, academic performance, visually impaired learners, integrated public primary schools

\section{Introduction}

Education is prioritized as a vital basic human right and it is made accessible to all the people regardless of their abilities as reported by (UNDP, 2005). Attainment of literacy and provision of education for all (EFA), as a basic human right, has shown that uneducated children or adults are great liabilities to the society (World Bank, 2015). Children Act legal framework, 1975 states that regulations and laws which primarily focus on our national education history and policies have been created to take care of education for the handicapped children. The world conference held in Dakar, Senegal in 2000 advocated for education for all (EFA). African countries such as Nigeria, Algeria, Congo have integration for physically challenged and VI learners where they set units within regular schools and adapt the curriculum to facilitate direct integration (UNESCO Journal, 1998). In East African countries, Tanzania started universal primary Education in 1970's, a step towards achieving education for all. On its part, Kenyan government established policies that govern special education for visually impaired and there have been Presidential and Ministerial directives towards provision of school resources and practice of integration. Integration is a policy which is implemented in many developing countries and Kenya set programmes as from 1988 to implement integration in schools. The Children's Act, (2001) embraced the principle for the best interest of all learners who have a right to education.

According to International Council for Education of people with Visually Impaired (ICEVI, 2010), in Africa, children who are blind are educationally vulnerable. It added that they begin school late, repeat classes, drop out early and do not access rehabilitation services. Sifuna (2007) observed that only $2.3 \%$ of VI learners in countries which are poor attend school. World Bank (2015) Global monitory report, of an estimated 77 million learners, more than a third have a disability, however developed countries have adopted a policy of focusing more on inclusion of VI learners within regular schools. According to MOE (2009), the 2003 Kochung Task Force recommended for the ratification of Special Needs Education policy to enhance the learning requirement for learners categorized to have SNE.

Kenya Integrated Education Program (KIEP) works together with the Ministry of Education in running SNE programs concurrently implementing government policies. The focus of KIEP indicates that it is to promote the education of VI learners in regular 
schools at county level. However, it is worth noting that EARC offices, assessment centers, VI learners in intergraded schools lack adequate resources learning materials like stylus, lenses, brail papers, CCTVS, brail machine, talking calculators and others low vision devices like lenses, large print papers CCTVS and activities of daily living from the experienced trained teachers on SNE. These are school resources such as learning materials, trained teaching staff, learning environment and special support services which directly affect academic performance of visually impaired learners. According to Argyropoulos \& Stamouli, (2006), inadequate tactical materials make visually impaired learners unable to learn and meet their academic performance. Kovács (2000) asserts that insufficient funding in regular schools find it difficult to meet the requirement of VI learners. According to the 2003 Disability Act, Kenya government should provide enabling vicinity for learners through curriculum adaptation, well trained staff, enough resources and ensuring there is accommodative physical infrastructure, conducive environment, and adequate support services for better academic performance of VI learners.

Although VI integrated schools adopt curriculum like the one applied in regular schools, the VI learners need more opportunities for advanced academic education and need a core curriculum to enable them to access all the curricular materials. These include orientation and mobility (OM), assistive technology like CCTVS, talking calculators, access and compensatory skills, social interaction, leisure, recreation and innovation, selfefficiency, determination, and sensory efficiency. Adaptation of curriculum means that the normal and regular curriculum is deliberately enriched to accommodate and maintain heterogeneous class (KISE, 2003). In integrated schools, VI learners should be given equal opportunity to manipulate the learning materials. VI learners cannot learn social skills incidentally or just casually, but they should be taught keenly sequentially and consciously thus manipulating learning materials through, social interaction, skills instruction is becoming impetus and fundamental. The learning materials like CCTVS, Abacus, Audio books, video tapes, computers softwares, diskettes, visually aids are important and make learning real and practical, influencing content and procedure of learning According to Vellymalay (2012), children's capacity to succeed depend on the successful guidance by teachers, parents, siblings as learners interact and manipulate with the surrounding classroom, learning materials they acquire skills, knowledge and attitude contributed by the environment.

Materials help VI learners review areas of learning, text books are efficient in terms of time and should allow adaptation and improvisation, learning materials like CCTVS, Abacus, audio books, video tapes embossers computers, calculators, brail papers, brail machine diskettes, visual aids, ductile materials, stylus are vital and make learning real, practical and interesting, influencing content, procedure of learning thus positively contributing to higher academic performance. 


\section{Statement of the Problem}

Kenyan government and non-governmental organization have attempted to support and to improve the quality of education and subsequently the academic achievement of Visually Impaired learners. Despite provision of free primary education (FPE), records at the County Director of Education indicate that there has been no visually impaired learner who has ever scored 250 marks out of the maximum 500 marks at Kenya Certificate of Primary Examination of. The government efforts have not been meet as envisaged by the Ministry of Education and Technology SNE policy implemented in public primary. This situation has been blamed on inadequacy of learning resources which impedes performance among visually impaired learners at KCPE (Baringo South Sub County Director of Education report- 2016). It is notable that schools are drifting from integration to special schools instead of the stakeholders focusing on inclusive education initiative which was meant to be realized by 2015. It is for this reason that this study sought to investigate the influence of school resources on the performance of visually impaired learners in public integrated primary schools in Baringo County. It specifically sought to answer the following questions.

1) In what ways do learning resources influence academic performance of visually impaired learners in integrated public primary schools in Baringo County?

2) How does barrier free learning environment influence academic performance of visually impaired learners in integrated public primary schools in Baringo County?

3) To what extent does available special support services influence academic of visually impaired learners in integrated public primary schools in Baringo County?

\section{Methodology}

The study adopted mixed methods methodology that uses both quantitative and quantitative which (Denzin and Lincoln,2005) observes that it is a method that investigates why and how of decision making and is ideal for smaller and focused samples, rather than large samples. The study employed descriptive survey research design that allows collection of information through interviews and questionnaires (Orodho, 2009). This study used a population of 501comprising 380 regular learners, 59 regular teachers 49 VI learners, 2 head teachers and 2 EARC officers. Using Krejcie and Morgan (1970) table of determining sample size, 298 respondents were drawn and included 191 regular learners, 49 teachers, 44 VI learners, 2 EARC officers and 2 head teachers. Simple random technique was used to draw regular learners, teachers and VI learners, while purposive sampling was used on EARC officers and head teachers. Questionnaires were used to collect quantitative data from teachers, sighted and VI learners while the EARC officers and head teachers were interviewed. Observation check list was also used to obtain observable information to complement data collected using 
the other three main research tools. The research instruments were validated appropriately, and the reliability of the questionnaire obtained by piloting in a neighboring County. A reliable 0.762 Cronbach alpha test score was obtained. Kathuri and Pals, (2003) points out that a 0.7 Cronbach alpha test score is appropriate. Quantitative data have been analyzed to obtain frequencies and percentages of responses, while qualitative data have been analyzed thematically as guided by the research objectives.

\section{Results and Discussions}

On the influence of learning resources on academic performance of visually impaired learners in integrated public primary schools in Baringo County, this study found out that the schools under study had brail machines and brail papers, talking calculators, abacus, embossers, and used adaptive curriculum. The headteachers and EARC officers concurred with the findings from pupils and teachers. The findings found out that these facilities to a great extent influenced the performance of the VI learners in the schools under study. This affirms Moodley (2017) assertion that there is needed to effectively provide and avail learning materials for V.I learners to aid in their learning process and to ensure that the integrated public primary schools meet their objectives. It is because of the importance of adequate teaching and learning resources to learners' performance that Okongo, Ngao, Rop \& Nyongesa (2015) recommended that adequate teaching and learning resources should be provided to ensure effective implementation of inclusive education and more funds to be allocated for procuring teaching and learning materials for special needs education (SNE) learners.

The findings further revealed that performance of VI learners in majority of schools was directly proportional to availability of necessary instructional resources which catered for the needs of the VI learners. This affirms Koech Report (1999) that the quality of services for the disabled learners are adversely affected by acute shortage of specialised aids, shortage of equipment, inappropriate curriculum inadequate staff support and specialist personnel, among others. Chisaka (2015) added that this leads to low performance in examination by candidates who are visually impaired at all levels. There were inadequate computers and minimal influence on VI academic performance. This concurs with Argyropoulus (2006) who stated that inadequate tactical materials make visually impaired learners unable to learn and meet their needs and finally contributing to poor academic performance.

The study established that the schools had ramps, pavement, and landmarks among other facilities to provided barrier free learning environment. The nature of the classroom for visually impaired learners influenced their academic performance a great deal though it needs improvement so improve performance. According to Okongo, Ngao, Rop \& Nyongesa (2015), it is important to have adequate instructional materials and physical facilities to support educational effort. Learning environment was a crucial element on performance of VI learners and needs to be availed and in good condition. 
However, Higgins and Ballard, (1999) noted that the faults of the mainstream resulted from too much attention and sympathy put on the disability of VI learner rather than changing the immediate environment this calls for the provision of barrier free learning environment by the school management. This is because Salamanca (1994) advocated for inclusion where learners should learn together with their non-handicapped peers hence barrier free environment facilitates integration and should facilitate accessible environment.

On being interviewed EARC officers and headteachers reported that learning environment needed modification since little has been done to make them friendly to the VI learners. According to Maingi-Lore (2016), to achieve functional levels of inclusion of special needs students in mainstream classes, it is imperative that certain modification and adaptation be made in existing educational resources and learning environment to enable these learners maximize their participation in the learning activities. They however observed that head teachers are expected to ensure that there is safe ground and barrier free environment for the learners in the institutions. The headteachers on their part noted that the school environment is not appropriate and not friendly at all to ease mobility of the learner.

The study further established that there were minimal provision of medical services, occupational therapy, and community support services. It therefore has had a negative influence of available special support services on academic performance of visually impaired learners in integrated public primary schools in Baringo County. This is despite the findings by Oyugi and Nyaga (2010) that teaching and learning resources include peripatetic services, support staff, community involvement, regular and special teachers, among others. Kochung (2011) added that inadequate trained special education teachers and professionals acts as an obstacle to implementation of inclusive education.

Oyugi and Nyaga (2010) note that teaching and learning resources include; peripatetic services, support staff (sign language interpreters and Braille transcribers), community involvement, regular and special teachers among others. Inadequate trained special education teachers and professional's acts as an obstacle to implementation of inclusive education (Kochung, 2011). On being interviewed, head teachers reported that learners' health was not monitored at all, and check-ups and referrals were not frequent. They noted that the teachers and parents need to attend workshops and seminars to be resourceful first line partners in assisting VI learners. The EARC added that provision of health services and referrals was required to maintain VI learners in the schools.

\section{Conclusions}

This study concludes that there were learning materials that included brail machines and brail papers, talking calculators, abacus, and embossers, and used adaptive curriculum. These facilities to a great extent influenced the academic performance of the VI learners in the schools Baringo County. However, there was need to provide computers and other assistive devices to enhance academic performance of VI learners. 
It further concludes that schools had ramps, pavement, landmarks among other facilities meant to provide barrier free learning environment. The nature of the classroom for visually impaired learners influenced their academic performance though it needs improvement so as to better their performance.

The study also concludes that in the study area, there were minimal provision of medical services, occupational therapy, and community support services. This situation had a negative influence on the academic performance of visually impaired learners in integrated public primary schools in Baringo County.

\section{Recommendations for Practice and Further Research}

This study recommends that:

1) The government of Kenya should allocate more funds for the provision of adequate learning materials; encourage adaptation of curriculum to enhance improvement of academic performance of visually impaired learners in integrated public primary schools.

2) More teachers should be trained on SNE especially on basic brail literacy to enable them to teach the children with visual impairment well and that the trained staff on SNE be distributed equitably to schools having integrated classes.

3) The government should also ensure that existing policies on SNE are effectively implemented, adhere to guidelines that ensure their actualization and school management ought to provide conducive barrier free learning environment.

4) Ministry of Education to sensitize parents on the importance of assessment, health services, seeking referrals and placement, and enrollment of children with visual impairment in integrated public primary schools in their early ages as stipulated by the government policy.

The study sought to find out how resources influence academic performance of VI learners and so recommends the following studies to be carried out,

1) The extent to which teachers influence academic performance of VI learners in Integrated primary schools.

2) The role of socio economic factors of parents on the academic performance of VI learners among Integrated Primary schools.

\section{Disclosure Statement}

We wish to confirm that there are no known conflicts of interest associated with this publication

\section{About the Authors}

Dinah Jepkorir Konga, is an MED candidate, Specialising in Special Needs Education among Visually Impaired Learners and serves as a teacher in an integrated primary school. Her research interests are on learning among VI Learners in integrated schools. 
Stephen Tomno Cheboi, Dr., is a Lecturer at Mount Kenya University, specializing in Educational Management. His research interests are on Teacher Education, Girl child Edu action, management of educational institutions and specializes in mixed methods approaches.

\section{References}

Argyropoulos, V.S. (2006). Braille Literacy Skills: An Analysis of the Concept of Spelling, Retrieved from https://www.researchgate.net/publication/288063420 Braille Literacy Skills An Analysis of the Concept of Spelling

Argyropoulos V. S., \& Stamouli, M. (2006). A Collaborative Action Research Project in an Inclusive Setting. Assisting a Blind Student. British Journal of visually impairment. 24(3), 128134.

Chisaka, W. I. (2015). Evaluation of factors Influencing the Visually Impaired Students Learning of Social Studies. A Case of Selected Teacher Training Colleges in Kenya. Unpublished Masters Thesis. Moi University, Kenya

Denzin, N. K. and Lincoln, Y. S. (2005). Introduction: The Discipline and Practice of Qualitative Research. In: Denzin, N. K. and Lincoln, Y. S., Eds., Handbook of Qualitative Research, 3rd Edition, Sage, Thousand Oaks, 1-32.

Higgins, N., \& Ballard, K. (1999). Case Studies: Reflections on the Meaning of Blindness in the Life Experiences of Four New Zealanders. British Journal of Visual Impairment. 17(1), 36-76.

ICEV (2010). International Council for Education of People with Visual Impairment Report

Kathuri, N. J. \& Pals, D. A. (2003). Introduction to Educational Research. Egerton University: Educational Media Centre.

Kenya Institute of Special Education (2003). Distance learning. Special needs education module 29 Curriculum development and adaptation. Nairobi: KISE.

Kochung, E. J. (2011). Role of Higher Education in Promoting Inclusive Education: Kenyan Perspective. Journal of Emerging Trends in Educational Research and Policy Studies, 2(3): 144-149; 2011.

Kovács, K. (2000). Hungary: Changing Attitudes in the Education of Children and Youth with a Visual Impairment. British Journal of Visual Impairment. 18(2), 61-66.

Krejcie, R. V., \& Morgan, D. W. (1970). Determining Sample Size for Research Activities. Educational and Psychological Measurement.

Maingi-Lore, M. (2016). Factors influencing Academic Performance of Students with Special Needs in Institutions of Higher Learning. The Case of Middle Level Colleges in Machakos County, Kenya. Unpublished Masters Project, University of Nairobi.

MOE, (2009). The National Special Needs Education Policy Framework 
Moodley, J. (2017). Education on the Equal Basis. A Comparison of Persons with and without Disabilities in South Africa. International Journal of Disability, Development and Education. Vol.64. Issue 3, p283-293

OECD, (2005). OECD Annual Report, 2005

Okongo, R. B., Ngao, G., Rop, N.K. \& Nyongesa, W. J. (2015). Effects of Availability of Teaching and Learning Resources on the Implementation of Inclusive Education in Pre-School Centers in Nyamira Sub-County Nyamira County Kenya. Journal of Education and Practice. Vol.6, no35

Orodho, J.A. (2009). Education and social science research methods. Nairobi: Harlifax printers and General supplies.

Oyugi, N. L \& Nyaga, M, M. (2010). Introduction to Contemporary Issues Affecting Education. Kenya Institute of Special Needs.

Republic of Kenya, (1999). Report of the Commission of Inquiry into the Education System of Kenya- The Koech Report

Sifuna, D. N. (2007). The Challenge of Increasing Access and Improving Quality: An Analysis of Universal Primary Education Interventions in Kenya and Tanzania since the 1970s. International Review of Education, v53 n5-6 p687-699 Nov 2007

UNDP (2005). Human Development Report; International Cooperation at a Crossroads, Aid, Trade and Security in an Unequal World. New York

UNESCO Secretariat (1998). World Education Report 1998: Teachers and Leaching in a changing world, UNESCO, Paris

Vellymalay, S. K. N. (2012). The Disadvantaged: Parental Involvement at Home and Low School Performance. International Journal of Asian Social Science. 2(7), p1161-1171

World Bank (2015). The World Bank Annual Report 2015. Washington, DC. 
Creative Commons licensing terms

Authors will retain the copyright of their published articles agreeing that a Creative Commons Attribution 4.0 International License (CC BY 4.0) terms will be applied to their work. Under the terms of this license, no permission is required from the author(s) or publisher for members of the community to copy, distribute, transmit or adapt the article content, providing a proper, prominent and unambiguous attribution to the authors in a manner that makes clear that the materials are being reused under permission of a Creative Commons License. Views, opinions and conclusions expressed in this research article are views, opinions and conclusions of the author(s). Open Access Publishing Group and European Journal of Special Education Research shall not be responsible or answerable for any loss, damage or liability caused in relation to/arising out of conflict of interests, copyright violations and inappropriate or inaccurate use of any kind content related or integrated on the research work. All the published works are meeting the Open Access Publishing requirements and can be freely accessed, shared, modified, distributed and used in educational, commercial and non-commercial purposes under a Creative Commons Attribution 4.0 International License (CC BY 4.0). 